\title{
Primary production of protein: II. Algal protein metabolism and its relation to particulate organic matter composition in the surface mixed layer*
}

\author{
Steven E. Lohrenz**, Craig D. Taylor, Brian L. Howes \\ Woods Hole Oceanographic Institution, Woods Hole, Massachusetts 02543, USA
}

\begin{abstract}
In situ comparisons were made in natural microbial populations between the fraction of particulate organic carbon (POC) which is particulate protein amino acid (PPAA) carbon, and the fraction of primary production allocated to PPAA synthesis. This approach was used to examine the relation between protein content of particulate organic matter (POM) and protein metabolism of the photoautotrophic population in the surface mixed layer of a marine pond (Salt Pond, Massachusetts, USA) throughout summer 1983. In general, ratios of algal production of PPAA carbon to total primary production (PPAA-P/P) were similar to ratios of PPAA carbon to total POC (PPAA-C/POC) measured in the standing POM. This indicated that the protein composition of POM reflected algal biosynthetic patterns. A bloom dominated by the brown flagellate Olisthodiscus magnus Hulburt occurred in late August. On one sampling date during the bloom decline, PPAA-P/P was significantly higher than PPAA-C/POC. This coincided with an increase in the primary production-related turnover time of the POC pool over that of the PPAA carbon pool, and a major shift in algal metabolism as evidenced by a change in the pattern of subcellular incorporation of ${ }^{14} \mathrm{C}$-carbon. Evidence to suggest that the bloom population was light-limited included decreases in chlorophyll-specific production $\left(\mathrm{P}^{\mathrm{B}}, \mu \mathrm{g} \mathrm{C} \mu \mathrm{g}\right.$ Chl $\mathrm{a}^{-1}$ $\mathrm{h}^{-1}$ ) and POC/chlorophyll a ratios which accompanied decreases in the percentages of surface light reaching $1 \mathrm{~m}$. There was also a significant correlation between the diffuse attenuation coefficient $(\mathrm{K}$, $\left.\mathrm{m}^{-1}\right)$ and $\ln \left(\mathrm{P}^{\mathrm{B}}\right)$ for the entire summer. The difference in PPAA-P/P and PPAA-C/POC ratios was explained by a decrease in primary production relative to PPAA production possibly due to light limitation and relating to a physiological transition of the photoautotrophic population. Selective removal of PPAA relative to POC by grazers and/or decomposition may have also contributed.
\end{abstract}

\section{INTRODUCTION}

Particulate organic matter (POM) in euphotic systems is a complex chemical matrix of primarily biological origin. Photoautotrophs account for the bulk of POM production in the euphotic zone of the world's oceans. The production and metabolism of biogenic compounds by photoautotrophs depend on environmentally-induced and intrinsic metabolic characteristics of the species making up the phytoplankton population (e.g. Morris 1981). However, the relation of chemical POM composition to biosynthetic metabolism of primary producers may be obscured by detritus as well as the presence and activities of other living

- Woods Hole Oceanographic Institution Contribution No. 6378

- Current address: Oceanographic Division, Code 333, Naval Ocean Research and Development Activity, NSTL, Mississippi 39529, USA organisms (e.g. Zeitschel 1970, Basne 1974, 1977, 1982, Beers et al. 1975, Eppley et al. 1977, Barlow 1982).

Because of the nutritional importance and chemical lability of particulate protein, its concentration in POM may affect the utilization efficiency by secondary consumers and the proportion of POM reaching the deep sea (e.g. Lee \& Cronin 1984). Knowledge of the relation between primary inputs of protein and particulate organic carbon (POC) and the relative abundances of protein and POC is useful in order to begin to understand the mechanisms which control protein flux and concentration in POM. Lohrenz \& Taylor (1987a) developed an approach whereby algal synthesis of particulate protein amino acids (PPAA) could be estimated accurately from short-term incubations in conjunction with standard estimates of primary production. We employed this method for estimating PPAA synthesis and primary production in natural populations of the surface mixed layer of a marine pond. In conjunc- 
tion, concentrations of PPAA and POC were determined. This permitted an unprecedented in situ comparison of the fraction of POC which is PPAA carbon and the fraction of primary production allocated to PPAA synthesis. Our results suggest that a close relationship existed between algal protein metabolism and the protein composition of the standing POM in the surface layer of the pond during our study. We did observe differences on one sampling date which we attributed to a major shift in the metabolic characteristics of the photoautotrophic population.

\section{METHODS}

Our study was conducted during summer 1983 in a small marine pond - Salt Pond, near Falmouth, Massachusetts, USA (Kim \& Emery 1971). Its semienclosed nature increased the probability that processes occurring within the pond ecosystem were primarily responsible for POM composition and abundance. The study site, designated by a permanent mooring with a small marker buoy, was centrally located and the water column depth was approximately $5.5 \mathrm{~m}$. Incubations conducted from 20 Jul 1983 through 10 Aug 1983 were performed using a 11 silane-treated glass syringe fitted with spring-powered polycarbonate pistons sealed with teflon ' $O$ ' rings and powered by teflon-coated springs. The unit was a later version of the instrument described by Taylor et al. (1983). For incubations conducted from 26 Aug 1983 through 3 Oct 1983, a dual chamber sampling and subsampling device was used which operated on the same principle, but with hydraulically driven pistons. The devices were suspended at the $1 \mathrm{~m}$ depth from a beam extending from the boat and oriented towards the sun to avoid shading. Mixing during the incubation was accomplished by the natural wave action of the boat, and by periodic manual agitation of the chambers.

Samples were procured in situ, simultaneously mixed with isotope solution, and incubation times kept relatively short ( 2 to $3 \mathrm{~h}$ ) thereby minimizing perturbations of population metabolism. Total radioactivity in the chamber was sampled by removing $50 \mu$ aliquots at various times throughout the incubation and placing them in $4 \mathrm{ml}$ Scintiverse II scintillation cocktail (Fisher) containing 50 ul Protosol (New England Nuclear).

Time course sampling of the chamber at $20 \mathrm{~min}$ intervals was accomplished by means of teflon tubing (1.5 $\mathrm{mm}$ ID) which extended to the surface. Samples of volume $30 \mathrm{ml}$ were drawn into darkened Luer-lok plastic syringes and immediately filtered $(<150 \mathrm{~mm} \mathrm{Hg})$ in $10 \mathrm{ml}$ aliquots on combusted $13 \mathrm{~mm}$ Whatman $\mathrm{GF} / \mathrm{F}$ filters held in Millipore (SYO0 13) polypropylene syringe filter holders. The filtration apparatus was shielded from direct sunlight. For determinations of total filter-retainable ${ }^{14} \mathrm{C}$, the filters were placed in $20 \mathrm{ml}$ glass scintillation vials and $0.1 \mathrm{ml}$ of $1 \mathrm{~N} \mathrm{HCl}$ was placed on the filter. The vials were capped and returned to the lab where the filters were dried at $55^{\circ} \mathrm{C}$ under a gentle air stream. The dried filters were moistened with a drop of deionized water, and $10 \mathrm{ml}$ scintillation fluid was added. Radioactivity was assayed with a Beckman LS100C liquid scintillation counter, and counts were corrected for quenching by the sample channels ratio method. Values were converted to $\mu \mathrm{g}$ carbon by dividing by the specific activity of the dissolved inorganic carbon pool. Specific activity of the inorganic carbon in the chambers ranged from 0.75 to $1.25 \mathrm{mCi}^{14} \mathrm{C} \mathrm{mmol}^{-1}$ inorganic carbon. Production rates were estimated by linear regression analysis of the time series of ${ }^{14} \mathrm{C}$ incorporation. The mean coefficient of variation for replicate incubations was $13 \%$.

Production of acid non-volatile ${ }^{14} \mathrm{C}$ was determined by bringing $3 \mathrm{ml}$ aliquots to a $\mathrm{pH}$ of 1.2 with a $3.16 \mathrm{~N}$ $\mathrm{H}_{2} \mathrm{SO}_{4}$ solution, transporting the closed vials back to the laboratory where they were sparged with air for $15 \mathrm{~min}, 17 \mathrm{ml}$ scintillation fluid added, and samples assayed for radioactivity as above. Acid non-volatile and filter-retained ${ }^{14} \mathrm{C}$-carbon measurements were virtually identical, indicating little accumulation of ${ }^{14} \mathrm{C}$ labeled dissolved organic carbon. Filter-retained rates are reported.

Dark uptake was determined by pumping samples through silicon tubing from the $1 \mathrm{~m}$ depth using a peristaltic pump (Cole-Parmer) into $50 \mathrm{ml}$ glass prescription bottles darkened with black tape. The isotope solution was added directly to the bottles, and bottles were incubated in situ. Individual bottles were removed and sampled at approximately hourly intervals, and the amount of acid non-volatile ${ }^{14} \mathrm{C}$ determined. Acid non-volatile ${ }^{14} \mathrm{C}$ present in dark bottle samples poisoned with $1 \%$ glutaraldehyde was determined to insure that there was no significant contamination of the ${ }^{14} \mathrm{C}$ stock solution.

For analysis of concentration of particulate protein amino acids (PPAA) and their incorporation of ${ }^{14} \mathrm{C}$. filters were immediately placed in $20 \mathrm{ml}$ glass scintillation vials containing $1.5 \mathrm{ml} 80 \%$ aqueous methanol. The vials were capped and returned to the laboratory and stored at $-6^{\circ} \mathrm{C}$ until analysis according to methods previously described by Lohrenz \& Taylor (1987a). PPAA production was estimated as the sum of regression rates of ${ }^{14} \mathrm{C}$-carbon incorporation into individual protein-bound amino acids which had been released from protein by hydrolysis, separated and quantified by high pressure liquid chromatography, and radioassayed. Measurements of total PPAA production were compared with individual measurements of protein- 
bound glycine synthesis which has precursors that rapidly equilibrate with the exogenous inorganic ${ }^{14} \mathrm{C}$ carbon pool (Lohrenz \& Taylor 1987a). This enabled the identification of effects of isotopic disequilibrium on total PPAA production estimates

Samples were also subjected to a subcellular fractionation procedure described in Lohrenz \& Taylor (1987b). This provided information about the distribution of assimilated ${ }^{14} \mathrm{C}$-carbon in alcohol-soluble (low molecular weight metabolites), ether-soluble (lipid), hot trichloroacetic acid-soluble (polysaccharides and nucleic acids), and residual protein fractions.

Transformation of labeled primary organic matter by grazers included in the incubation vessel was assumed to be negligible. Given the short incubation periods used in this study ( 2 to $3 \mathrm{~h}$ ), a significant fraction of algal biomass would have to be consumed during the incubation period in order to observe an effect. However, this would have led to a nonlinear decrease in carbon incorporation rates. For the majority of incubations conducted, short-term uptake of ${ }^{14} \mathrm{C}$-inorganic carbon was effectively linear $\left(r^{2}>0.9, n \geqslant 6\right)$, and consequently, radiocarbon distributions were assumed to reflect algal biosynthetic activities.

Water samples for temperature, salnity, chlorophyll $a_{1}$ ammonium, nitrate, nitrite, orthophosphate, particulate organic carbon, and dissolved inorganic carbon were collected into well-flushed polypropylene bottles through a silicon tube using the peristaltic pump. Bottles were filled with no headspace. Temperature was measured immediately. The bottles were returned to

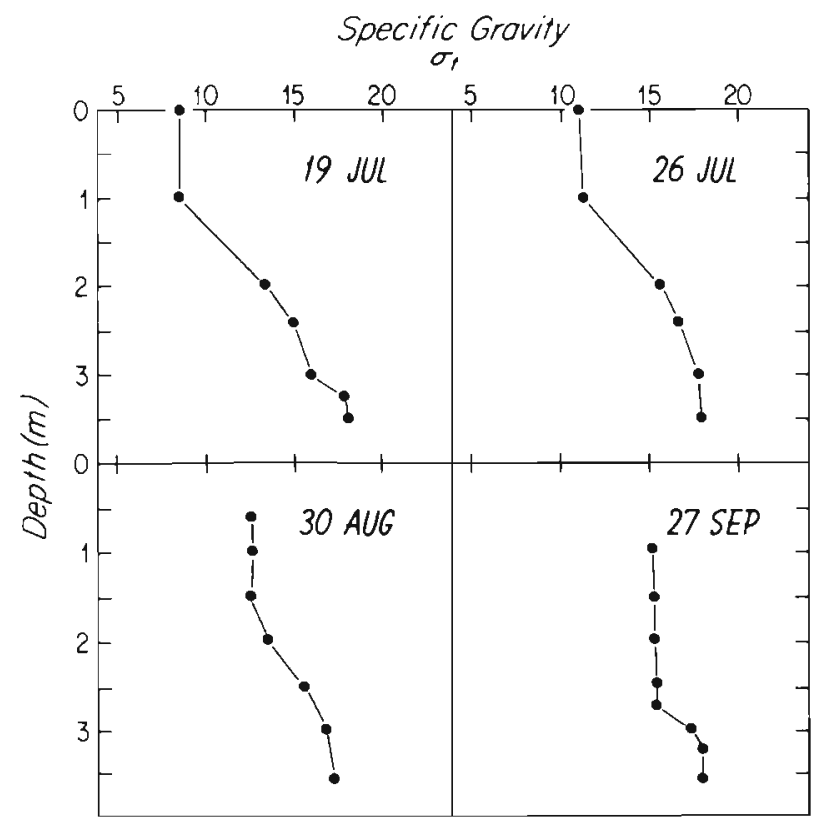

Fig. 1. Depth profiles of specific gravity $\left(\sigma_{t}\right)$ during study period in Salt Pond. $\sigma_{t}=\left[\left(\right.\right.$ density of seawater at $t{ }^{\circ} \mathrm{C} /$ density of pure water at $\left.\left.4^{\circ} \mathrm{C}\right)-1\right] 1000$ after Cox et al. (1970) the laboratory and stored at $5^{\circ} \mathrm{C}$ until processing (within $2 \mathrm{~h}$ of collection). Salinity was determined using a Goldberg temperature compensated refractometer, and conventional specific gravity was calculated from temperature and salinity (Cox et al. 1970). For nutrient analyses, filtrates from rinsed Whatman $\mathrm{GF} / \mathrm{F}$ filters were collected into acid-cleaned $50 \mathrm{ml}$ polypropylene bottles and frozen $\left(-20^{\circ} \mathrm{C}\right)$ until analysis with a Technicon nutrient autoanalyser. Other chemical analyses were described in Lohrenz \& Taylor (1987a).

Continuous measurements of photosynthetically active $(400$ to $700 \mathrm{~nm})$ surface quantum scalar irradiance were made during incubations using a Biospherics quantum light meter equipped with a $4 \mathrm{pi}$ spherical probe and interfaced with a chart recorder (Scientific Products). Depth profiles of photosynthetically active radiation were measured in the mixed layer using a submersible Li-Cor cosine quantum sensor, and the diffuse attenuation coefficient, $\mathrm{K}\left(\mathrm{m}^{-1}\right)$, was determined from linear regression analysis of the relationship of depth versus $\ln$ [photon flux density].

\section{RESULTS}

Salt Pond typically possesses a shallow surface mixed layer. Profiles of conventional specific gravity during the summer indicated a mixed layer depth ranging between 1.0 and $3.0 \mathrm{~m}$, as indicated by a distinct pycnocline in this depth range (Fig. 1). On the days when incubations were conducted, chlorophyll $a$ and total pigment concentrations were generally uniform throughout the upper 1.0 to $1.5 \mathrm{~m}$ (Fig. 2). Langmuir circulation was commonly observed in Salt Pond as evidenced by distinct slicks (convergence zones) interspersed by 1 to $3 \mathrm{~m}$ between turbulent areas (divergence zones). Surface movement of fluorescein dye averaged $>0.3 \mathrm{~m} \mathrm{~s}^{-1}$ during one such period. These observations support the view that the surface layer was well-mixed during this study.

Seasonal variations in chlorophyll $\boldsymbol{a}$, POC, and PPAA carbon (PPAA-C) concentrations are illustrated in Fig. 3. During the latter part of August, increases occurred which were associated with a bloom of a brown flagellate identified as Olisthodiscus magnus (Hulburt 1965).

Rates of primary production from the period $20 \mathrm{Jul}$ to 3 Oct are shown in Table 1, along with dark uptake rates. Rates differed for consecutive morning and midday incubations, although there was no indication of a trend with time of day. Differences on 26 Aug and 3 Oct could to some extent be related to natural variations in the surface light regime (data not shown). The difference on $1 \mathrm{Sep}$ was attributed to a difference in 


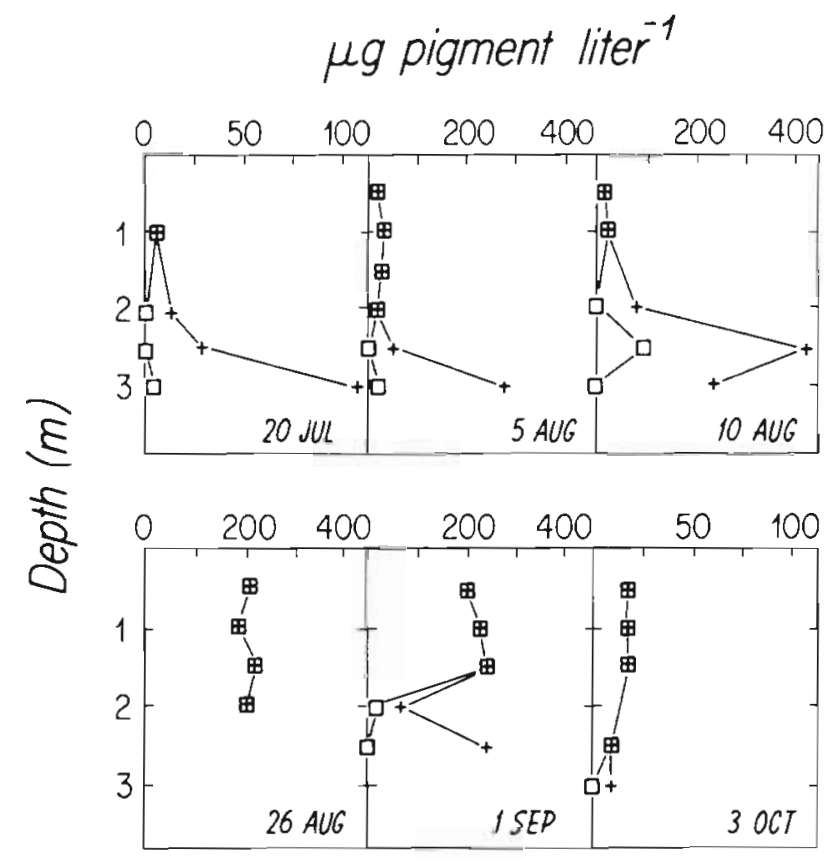

Fig. 2. Depth profiles of chlorophyll a on days during which incubations were conducted. ( $\square$ ) Chlorophyll $a_{;}(+)$total pigments (phaeopigments + chlorophyll a). Note changes in scale on different dates

biomass concentrations in the morning and midday incubation chambers (protein-bound glycine in the morning incubation was $0.053 \mathrm{mg} \mathrm{Cl}^{-1}$ [standard error $=0.003, \mathrm{n}=6]$ compared with $0.027[0.002, \mathrm{n}=5]$ in the midday incubation. Dark fixation of ${ }^{14} \mathrm{C}$-inorganic carbon was generally low in comparison with rates in the light (Table 1) except on 20 Jul when it was approximately $25 \%$ of the fixation rate in the light. However, because of a large standard error the dark rate on $20 \mathrm{Jul}$ was not significantly different from zero. The otherwise low rates of dark fixation indicated that the bulk of inorganic carbon fixation was by photoauto-

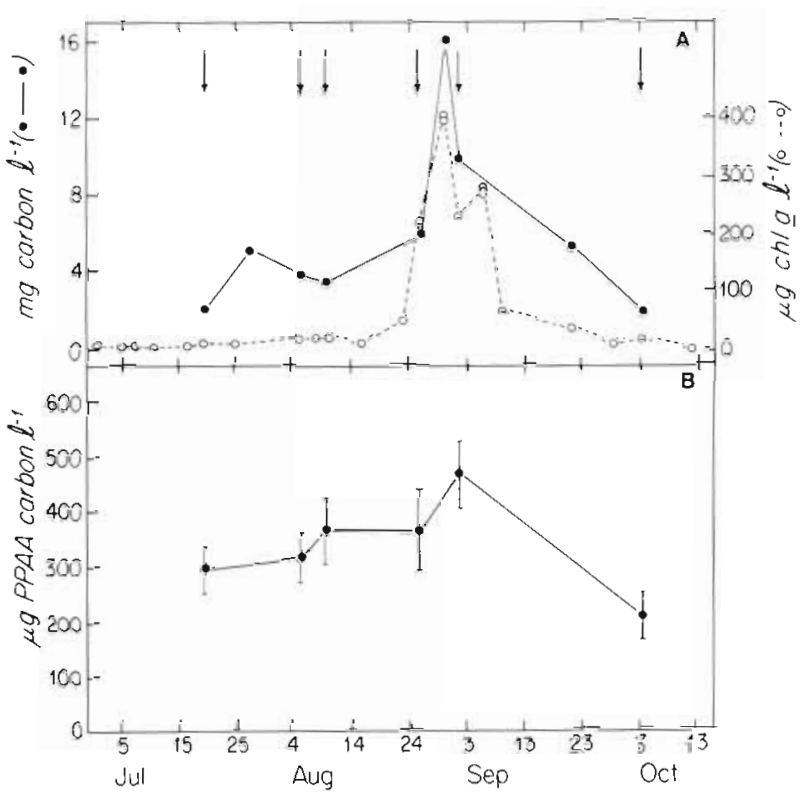

Fig. 3. (A) Particulate organic carbon and chlorophyll a concentrations at $1 \mathrm{~m}$ in Salt Pond mixed layer; means of replicate measurements. Arrows: dates on which productivity measurements were made. (B) Particulate protein amino acid concentrations. Error bars: 2 standard errors of means ( $\mathrm{n}=5$, except 26 Aug $n=4$ )

trophs, and no corrections were applied.

A highly significant correlation $(r=-0.9200 ; p$ $<0.005)$ was found between the diffuse attenuation coefficient $\left(K, \mathrm{~m}^{-1}\right)$ and the natural logarithm of chlorophyll-specific production $\left(\mathrm{P}^{\mathrm{B}}, \mu \mathrm{g} \mathrm{C} \mu \mathrm{g} \mathrm{Chl} a^{-1}\right.$ $\mathrm{h}^{-1}$ ), suggesting that light limitation influenced production. Evidence that light limitation was particularly important during the bloom (Fig. 4) was the pronounced decrease in $\mathrm{P}^{\mathrm{B}}$ (Fig. $4 \mathrm{C}$ ) and POC/chlorophyll a ratio (Fig. 4D) which accompanied the decrease in the percentage of surface light reaching $1 \mathrm{~m}$ (Fig. $4 \mathrm{~B}$ ).

Nutrient levels were, for the most part, relatively

Table 1. Particulate organic carbon production and dark ${ }^{14} \mathrm{C}$ uptake rates $\left(\mu g \mathrm{C}^{-1} \mathrm{~h}^{-1}\right)$ for consecutive incubations

\begin{tabular}{|c|c|c|c|c|c|c|c|}
\hline Date & Time of day & $\begin{array}{c}\text { POC } \\
\text { production }\end{array}$ & SE & $\mathrm{n}$ & $\begin{array}{c}\text { Dark } \\
\text { uptake }\end{array}$ & $\mathrm{SE}$ & $\mathrm{n}$ \\
\hline $20 \mathrm{Jul} 83$ & $1240-1510$ & 37 & 0.65 & 14 & 10 & 3.9 & 6 \\
\hline 5 Aug 83 & $1240-1435$ & 59 & 1.0 & 20 & 1.4 & 0.14 & 8 \\
\hline 10 Aug 83 & $1250-1515$ & 45 & 0.83 & 17 & -0.6 & 0.55 & 7 \\
\hline \multirow[t]{2}{*}{26 Aug 83} & $0930-1250$ & 25 & 4.3 & 6 & nd & - & - \\
\hline & $1130-1415$ & 34 & 1.8 & 6 & -0.30 & 1.1 & 8 \\
\hline \multirow[t]{2}{*}{1 Sep 83} & $0900-1200$ & 47 & 2.8 & 13 & nd & - & - \\
\hline & $1050-1400$ & 21 & 0.23 & 12 & 0.70 & 0.45 & 7 \\
\hline \multirow[t]{2}{*}{3 Oct 83} & $0815-1050$ & 59 & 2.8 & 12 & nd & - & - \\
\hline & $1010-1230$ & 87 & 1.4 & 11 & $-13^{\cdot}$ & 3.0 & 8 \\
\hline
\end{tabular}

SE: standard error; nd: not determined. - Significant negative rate resulted from initially high value followed by a decline 


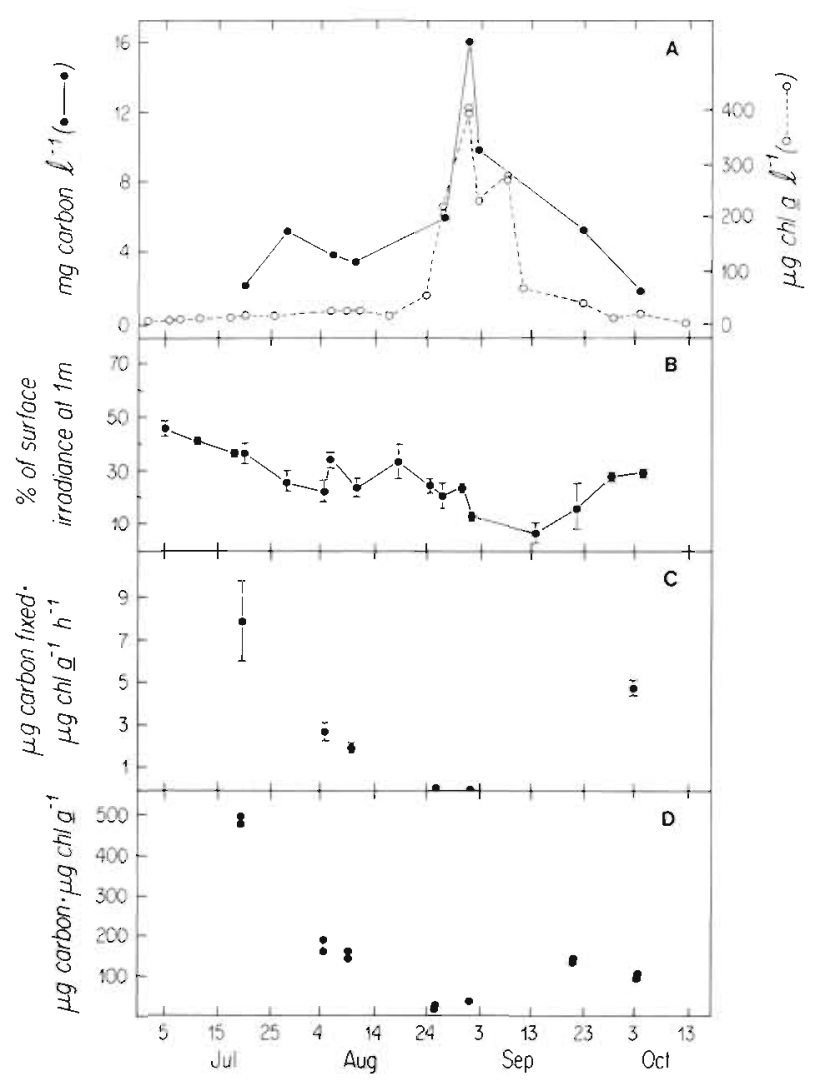

Fig. 4. (A) As in Fig. 3A. (B) Percentage of surface irradiance reaching $1 \mathrm{~m}$; error bars: 2 standard errors of means, $n \geq 4$. (C) Chlorophyll-specific primary production at $1 \mathrm{~m}$; errors as in (B); errors on 26 Aug and $1 \mathrm{Sep}$ were within symbols. (D) Particulate organic carbon to chlorophyll a ratios. Replicate determinations shown for each sample

high and quite variable (Fig. 5). The periodic increases in ammonium concentrations not accompanied by increases in either phosphate or nitrate indicated that the most likely source of the ammonium peaks was entrainment across the pycnocline as a result of mixing events. During late July, sampling below the surface layer at $3 \mathrm{~m}$ revealed low oxygen levels $\left(<1.0 \mathrm{ml} \mathrm{l}^{-1}\right)$ and undetectable nitrate, while concentrations of ammonium ranged between 5 to $17 \mu \mathrm{M}$ and phosphate less than $0.2 \mu \mathrm{M}$. The relative levels of these nutrients were consistent with the view that this water was the source of the ammonium peaks. A curious result was the large peak in orthophosphate concentration which accompanied the increase in POC and chlorophyll a during the bloom (Fig. 5B). We believe this was real since the trend was reflected in several samples; however, we can offer no obvious explanation. Possibly, it resulted from enhanced release of organically-bound phosphorus during that period.

Midday rates of PPAA production (PPAA-P) and production of protein-associated glycine (GLY-P) are expressed as a percentage of total primary production (P, $\left.\mu g \mathrm{C}^{-1} \mathrm{~h}^{-1}\right)$ in Fig. 6. PPAA-P/P ranged from 5 to
$14 \%$ (Fig. 6B), and GLY-P/P from 0.4 to $1.4 \%$ (Fig. 6C). GLY-P can be extrapolated to PPAA-P by dividing by the mean fraction of protein carbon in glycine determined for laboratory cultures 10.055 , Lohrenz \& Taylor 1987 a). This yields a range of 7 to $25 \%$ for extrapolated PPAA-P/P, slightly higher than the measured range. The difference was expected since precursor pools of some other protein-bound amino acids do not equilibrate as rapidly with the inorganic ${ }^{14} \mathrm{C}$-carbon pool (Lohrenz \& Taylor 1987a).

Our main objective in this investigation was to determine whether the relative synthesis of PPAA and POC by photoautotrophs (i.e. PPAA-P/P) reflected the relative abundance of PPAA and POC (i.e. PPAA-C/POC). The percentage ratios, PPAA-P/P and PPAA-C/POC are compared in Fig. 6B, and GLY-P/P and GLY-C/ POC compared in Fig. 6C. Variances of these ratios were determined to be homogeneous and differences were evaluated using the t-statistic (Sokal \& Rohlf 1969). In general on a given day, the ratios were not statistically different. A significant difference did occur during the bloom decline on 1 Sep., when PPAA-P/P was significantly higher than PPAA-C/POC $(p<0.05)$ and GLY-P/P significantly higher than GLY-C/POC ( $p$

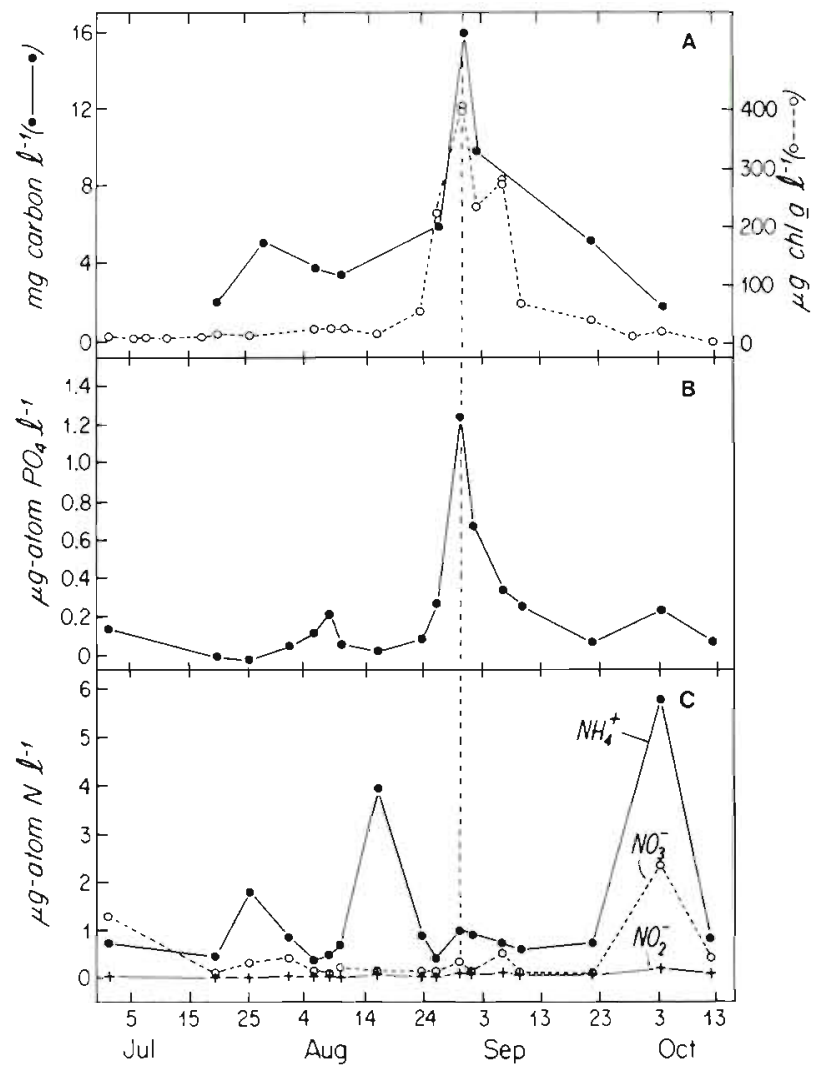

Fig. 5. (A) As in Fig. 3A. (B) Orthophosphate concentrations at $1 \mathrm{~m}$. (C) Ammonium, nitrate and nitrite concentrations. Dashed vertical line: reference to peaks in POC and chlorophyll a 


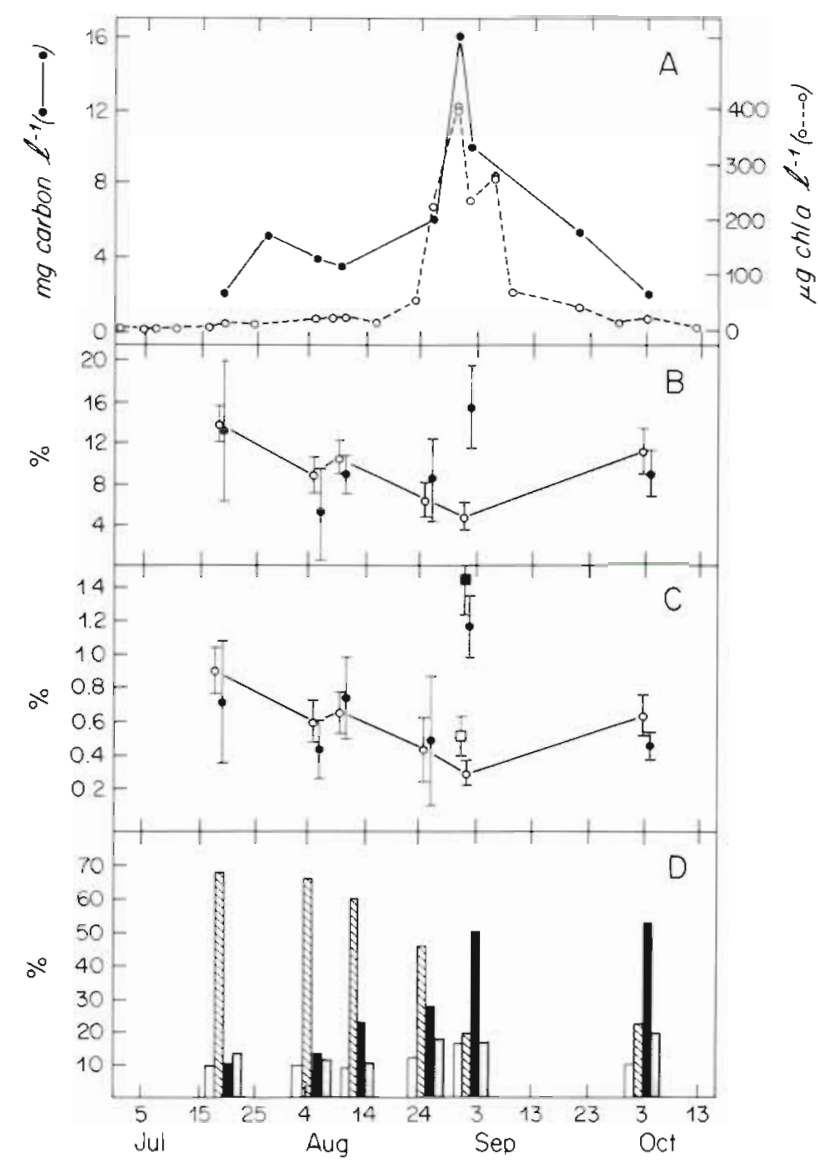

Fig. 6. (A) As in Fig. 3A. (B) Ratio of protein synthesis to total primary production, PPAA-P/P (solid circles), compared with ratio of protein carbon to total particulate organic carbon, PPAA-C/POC (open circles); ratios expressed as percentages; errors represent 2 standard errors of means. (C) Ratio of protein-associated glycine synthesis to total primary production, GLY-P/P (solid circles), compared with ratio of glycine carbon to total particulate organic carbon, GLY-C/POC (open circles). (D) Percentage distributions of ${ }^{14} \mathrm{C}$-carbon incorporation associated with different subcellular fractions. Open bar: residual protein; hatched bar: polysaccharide and nucleic acids; solid bar: low molecular weight metabolites; stippled bar: lipids

$<0.01$ ) (Fig. 6B, C). To verify that these differences were not associated with a single incubation event, GLY-P/P and GLY-C/POC were compared in an earlier incubation on the same day (Fig. 6C, square symbols). Differences were again found to be significant ( $p$ $<0.01$ ). Total PPAA synthesis was not determined for the earlier incubation. The consistency of independent data sets indicates that the observed synthesis versus standing stock differences could not be attributed to a single sampling event, but rather reflected real differences between the protein metabolism of the autotrophic population and the composition of POM.

Concurrently, a major change in the pattern of subcellular incorporation of ${ }^{14} \mathrm{C}$-carbon (Fig. 6D) was observed on $1 \mathrm{Sep}$. The fraction of assimilated ${ }^{14} \mathrm{C}$ - carbon in polysaccharides and nucleic acids decreased by more than a factor of 2 and the fraction in low molecular weight metabolites approximately doubled. Subsequent sampling on 3 Oct revealed a relative distribution similar to that on 1 Sep, indicating a significant transition in algal metabolism had occurred on or around 1 Sep.

The substantial changes in algal metabolism were accompanied by an increase in the primary productionrelated turnover time of the POC pool (i.e. the time required for the $\mathrm{POC}$ pool to turnover once if primary production was the sole input of POC). In contrast, change was less apparent in the turnover of PPAA-C and GLY-C pools. To illustrate this, hourly estimates of P, PPAA-P, and GLY-P were multiplied by 11, the number of hours in the photoperiod, to give daily production estimates: $P_{d}$, PPAA- $P_{d}$ and GLY-P $P_{d}$. POC $/ P_{d}$ ratios were generally similar to PPAA-C/PPAA- $P_{d}$ and GLY-C/GLY-P $\mathrm{P}_{\mathrm{d}}$ ratios except for 1 Sep during the bloom decline (Table 2). On this day, POC/ $\mathrm{P}_{\mathrm{d}}$ increased dramatically while there was little apparent change in PPAA-C/PPAA-P $P_{d}$ and GLY-C/GLY-P . Our estimates of daily production are only approximate since diel variations in primary production (e.g. Harding et al. $1982 \mathrm{a}$, b) respiratory carbon loss (e.g. Falkowski \& Owens 1978), and night protein synthesis (e.g. Cuhel et al. 1984) were not taken into account. We attempted to minimize between-day differences resulting from diel variations by sampling at approximately the same time of day (Table 1), and it is unlikely that night synthesis and respiration could account for the differences in turnover times observed on 1 Sep.

\section{DISCUSSION}

This study is a first attempt to determine the relationship between inputs of POC and PPAA into a euphotic system by primary producers, and the relative abundances of POC and PPAA in the standing POM. Our results show that PPAA synthesis and PPAA-associated carbon generally accounted for similar proportions of primary production and POC respectively (Fig.6). Similarly, investigations of a specific PPAA, glycine, also showed a correspondence between the proportion of primary production allocated to synthesis of proteinbound glycine, and the proportion of POC contained in protein-bound glycine. These results indicate that sources of POM other than algal primary production were either relatively small or resulted in a net contribution of POM of similar protein composition.

Previous investigations have compared the relation of carbon and nitrogen assimilation by natural phytoplankton populations to the relative abundance of POC and particulate organic nitrogen (e.g. Eppley et al. 
Table 2. POC, PPAA carbon, and protein-associated glycine carbon pool concentrations (mgC $1^{-1}$ ) and primary production-related turnover times $\left(\mathrm{mgC} \mathrm{l}^{-1} / \mathrm{mgC} \mathrm{l}^{-1} \mathrm{~d}^{-1}\right)$

\begin{tabular}{|c|c|c|c|c|c|c|}
\hline \multirow[t]{2}{*}{ Date } & \multicolumn{3}{|c|}{ Pool concentrations } & \multicolumn{3}{|c|}{ Turnover times } \\
\hline & POC & PPAA-C & GLY-C & $\frac{P O C}{P_{d}}$ & $\frac{\text { PPAA-C }}{\text { PPAA-P }}$ & $\frac{G L Y-C}{G L Y-P_{d}}$ \\
\hline $20 \mathrm{Jul} 83$ & 2.2 & 0.29 & 0.019 & 5.4 & 5.4 & 6.6 \\
\hline 5 Aug 83 & 3.6 & 0.31 & 0.021 & 5.9 & 10 & 7.7 \\
\hline 10 Aug 83 & 3.2 & 0.36 & 0.023 & 6.7 & 8.8 & 6.7 \\
\hline 26 Aug 83 & 5.9 & 0.36 & 0.024 & 18 & 12 & 14 \\
\hline 1 Sep 83 & 10.0 & 0.46 & 0.027 & 43 & 14 & 10 \\
\hline 3 Oct 83 & 2.0 & 0.20 & 0.012 & 2.1 & 2.4 & 2.7 \\
\hline
\end{tabular}

1977, 1979, Slawyk et al. 1978, Sharp et al. 1980, Harrison et al. 1982). Unlike our results suggesting a similarity between relative synthesis rates of $\mathrm{POC}$ and PPAA, and their relative abundance in POM, C:N assimilation ratios were generally quantitatively different from, although positively correlated with, the ratios in POM. Both larger and smaller assimilation ratios were observed, and the range was much larger than for elemental ratios in standing POM. Such discrepancies may be attributable to the fact that nitrogen uptake rates can be time-varying and uncoupled from carbon incorporation (Collos \& Slawyk 1979, Goldman et al. 1981).

We observed that PPAA-P/P and GIY-P/P were higher than PPAA-C/POC and GLY-C/POC respectively only on 1 Sep during the bloom decline. Differences for glycine were observed in 2 separate incubations at different times of day. It is unlikely that diel changes in phytoplankton physiology were responsible for these differences. This would have required either production of POC or preferential catabolism of protein relative to other cell material during the night hours. Neither of these possibilities is supported by previous observations of preferential conservation of protein at the expense of storage material during the dark period in synchronous laboratory cultures grown in light/dark cycles (Handa 1969, Darley et al. 1976, Lorenzen \& Kaushik 1976, Van Liere et al. 1979, Hitchcock 1980).

The observed difference between PPAA-P/P and PPAA-C/POC apparently signaled a period of transition in the metabolism of the photoautotrophic population possibly associated with the physiological decline of the bloom species. Major differences in algal carbon metabolism were observed on this date (Fig. 6D). Such biosynthetic measurements reflect the metabolism of viable species, while the biomass composition at that time may have reflected predominately inactive algal cells.

There was evidence to suggest that light limitation contributed to the bloom decline. The percentage of surface light penetrating to $1 \mathrm{~m}$ was low at that time (Fig. 4B), as were values of chlorophyll-specific production $\left(\mathrm{P}^{\mathrm{B}}, \mu \mathrm{g} \mathrm{C} \mu \mathrm{g} \mathrm{Chl} a^{-1} \mathrm{~h}^{-1}\right)$ and carbon to chlorophyll ratios (Fig. 4C, D). Furthermore, there was a significant correlation between the diffuse attenuation coefficient $\left(K, \mathrm{~m}^{-1}\right)$ and $\ln \left(\mathrm{P}^{\mathrm{B}}\right)$. Nutrient limitation seems unlikely since both ammonium and orthophosphate were measurable throughout the bloom (Fig. 5). However, limitation by trace nutrients not measured cannot be ruled out.

Sharp gradients in light intensity with depth may have contributed to the differences on 1 Sep between PPAA-P/P and PPAA-C/POC, and between GLY-P/P and GLY-C/POC. Previous studies have illustrated that both laboratory cultures and natural populations shifted to lower light intensities may respond with higher relative incorporation of ${ }^{14} \mathrm{C}$-carbon into protein-associated subcellular fractions (Morris et al. 1974 , Konopka \& Schnur 1980, Lohrenz 1985). In support of the argument that a decrease in total primary production relative to PPAA production occurred was the large increase in the primary production-related turnover time of the POC pool over that of the PPAA and glycine pools (Table 2). This was in contrast to the relative similarity in turnover of the POC, PPAA and glycine pools and their relatively unvarying concentrations before the bloom (Table 2), an indication that there had previously been a tight coupling between synthesis and removal of both POC and PPAA.

Other explanations for the fact that algal synthesis of PPAA-C relative to POC was higher than their relative abundance in the standing POM include dilution of algal POM by PPAA-depleted bacterial production. However, Fukami et al. (1985) found that decomposing algal material was initially enriched in protein due to colonization by bacteria. Alternatively, selective grazing of protein-enriched organic matter could result in enhanced PPAA removal. Investigations with the 
bloom species' congener, Olisthodiscus luteus, found it to be relatively unpalatable to zooplankton (Tomas \& Deason 1981, Verity \& Stoecker 1982). This leads to speculation that more biosynthetically active algal species were responsible for the high relative synthesis of PPAA, and were preferentially grazed relative to the O. magnus population. Differential susceptibilities of POC and PPAA to decomposition could also lead to selective removal of protein. Levels of PPAA in POM have been shown to decrease with depth and such losses are enhanced in more productive areas (Lee \& Cronin 1984).

On the basis of our results we conclude that the protein composition of POM in the Salt Pond mixed layer during this study generally reflected the patterns of biosynthesis of the algal population within the limits of analytical precision. We attribute the observed difference between PPAA-P/P and PPAA-C/POC on 1 Sep to a major shift in algal population metabolism, apparently associated with low light levels and relating to the decline of the bloom. Selective removal of PPAA from POM, including selective grazing of viable algal species and enhanced decomposition of protein may have also contributed to observed differences.

The present investigation has illustrated a unique approach for investigating the relationships between the ambient levels of individual biogenic compounds and the characteristics of organisms which influence them. Our study has shown how the combined measurements of both biosynthetic activity and standing composition can provide a better understanding of changes in population metabolism than would be possible with either type of measurement alone. Identification of differences between relative synthesis rates of biogenic compounds and ratios in standing POM may serve as a flag for further investigation of potential changes in growth and physiological state of autotrophic populations.

Acknowledgements. Financial support for this research was provided by the Woods Hole Oceanographic Institution Coastal Research Center through a grant from the Andrew W Mellon Foundation, by the National Science Foundation (OCE-82-15854, BSR-84-18268), and by the Woods Hole Oceanographic Institution Education Department. We are grateful to C. Lee, J. J. Molongoski, and M. E. Lakich for helpful comments. We also thank Bonnie Woodward for particulate organic carbon and nitrogen analyses, E. M. Hulburt for phytoplankton species identification, Z. Mlodzinska for nutrient analyses, and $M$. Knapp for technical assistance.

\section{LITERATURE CITED}

Banse, K. (1974). On the role of bacterioplankton in the Tropical Ocean. Mar. Biol. 24: 1-5

Banse, K. (1977). Determining the carbon-to-chlorophyll ratio of natural phytoplankton. Mar Biol. 41: 199-212
Banse, K. (1982). Cell volumes, maximal growth rates of unicellular algae and ciliates, and the role of ciliates in the marine pelagial. Limnol. Oceanogr 27: 1059-1071

Barlow, R. G. (1982). Phytoplankton ecology in the southern Benguela current. I. Biochemical composition. J. exp. mar. Biol. Ecol. 63: 209-227

Beers, J. R., Reid, F. M. H., Stewart, G. L. (1975). Microplankton of the North Pacific Central Gyre. Population structure and abundances, June 1973. Int. Revue ges. Hydrobiol. 60: $607-638$

Collos, Y., Slawyk, G. (1979). $13 \mathrm{C}$ and $15 \mathrm{~N}$ uptake by marine phytoplankton. I. Influence of nitrogen source and concentration in laboratory cultures of diatoms. J. Phycol. 15: 186-190

Cox, R. A., McCartney, M. J., Culkin, F. (1970). The specific gravity/salinity/temperature relationship in natural sea water. Deep Sea Res. 17: 679-689

Cuhel, R. L., Ortner, P. B., Lean, D. R. S. (1984). Night synthesis of protein by algae. Limnol. Oceanogr. 29: 731-744

Darley, W. M., Sullivan, C. W., Volcani, B. E. (1976) Studies on the biochemistry and fine structure of silica shell formation in diatoms. Division cycle and chemical composition of Navicula pelliculosa during light-dark synchronized growth. Planta 130: 159-167

Eppley, R. W., Harrison, W. G., Chisholm, S. W., Stewart, E. (1977). POM in surface waters off southern California and its relationship to phytoplankton. J. mar. Res. 35: 671-696

Eppley, R. W., Renger, E. H., Harrison, W. G. (1979). Nitrate and phytoplankton production in southern California coastal waters. Limnol. Oceanogr. 24: 483-494

Falkowski, P. G., Owens, T. G. (1978). Effects of light intensity on photosynthesis and dark respiration in six species of marine phytoplankton. Mar. Biol. 45: 289-295

Fukami, K., Simidu, U., Taga, N. (1985). Microbial decomposition of phyto- and zooplankton in seawater. I. Changes in organic matter. Mar. Ecol. Prog. Ser 21: 1-5

Goldman, J. C., Taylor, C. D., Glibert, P. M. (1981). Nonlinear time-course uptake of carbon and ammonium by marine phytoplankton. Mar Ecol. Prog. Ser. 6: 137-148

Handa, N. (1969). Carbohydrate metabolism in the marine diatom, Skeletonema costatum. Mar. Biol. 4: 208-214

Harding, L. W., Jr., Prezelin, B. B., Sweeney, B. M., Cox, J. L. (1982a). Diel oscillations of the photosynthesis-irradiance (P-I) relationship in natural assemblages of phytoplankton. Mar Biol. 67: 167-178

Harding, L. W., Jr., Prezelin, B. B., Sweeney, B. M., Cox, J. L. (1982b). Primary production influenced by diel periodicity of phytoplankton photosynthesis. Mar Biol. 67: 179-186

Harrison, W. G., Platt, T., Irwin, B. (1982). Primary production and nutrient assimilation by natural phytoplankton populations of the eastern Canadian Arctic. Can. J. Fish. Aquat. Sci. 39: 335-345

Hitchcock, G. L. (1980). Diel variation in chlorophyll a. carbohydrate and protein content of the marine diatom Skeletonema costatum. Mar. Biol. 57: 271-278

Hulburt, E. M. (1965). Flagellates from brackish waters in the vicinity of Woods Hole, MA. J. Phycol. 1: 87-95

Kim, C. M., Emery, K. O. (1971). Salt Pond: topography, sediments, and water. Salt Pond Bird Sanctuaries, Inc., Annual Report 1971, Falmouth, Massachusetts

Konopka, A., Schnur, M. (1980). Effect of light intensity on macromolecular synthesis in cyanobacteria. Microb. Ecol. 6: 291-301

Lee, C., Cronin, C. (1984). Particulate ammo acids in the sea: effects of primary production and decomposition. J. mar Res. 42: 1075-1097

Lohrenz. S. E. (1985). Primary production of particulate pro- 
tein amino acids: algal protein metabolism and its relationship to the composition of POM. Ph. D. thesis, Massachusetts Institute of Technology/Woods Hole Oceanographic Institution, WHOI-85-24

Lohrenz, S. E., Taylor, C. D. (1987a). Primary production of protein: I. Comparison of net cellular carbon and protein synthesis with ${ }^{14} \mathrm{C}$-derived rate estimates in steady-state cultures of marine phytoplankton. Mar. Ecol. Prog. Ser. 35: $277-292$

Lohrenz, S. E., Taylor, C. D. (1987b). Inorganic ${ }^{14} \mathrm{C}$ as a probe of growth date-dependent variations in intracellular free amino acid and protein composition of $\mathrm{NH}_{4}^{+}$-limited continuous cultures of Nannochloris atomis Butcher. J. exp. mar. Biol. Ecol. 106: 31-55

Lorenzen, H., Kaushik, B. D. (1976). Experiments with synchronous Anacystis nidulans. Ber. dt. bot. Ges. 89: $491-498$

Morris, I. (1981). Photosynthetic products, physiological state, and phytoplankton growth. Can. Bull. Fish. Aquat. Sci. 210: 83-102

Morris, I., Glover, H. E., Yentsch, C. S. (1974). Products of photosynthesis by marine phytoplankton: the effect of environmental factors on the relative rates of protein synthesis. Mar. Biol. 27: 1--9

Sharp, J. H., Perry, M. J., Renger, E. H. (1980). Phytoplankton rate processes in the oligotrophic waters of the central North Pacific Ocean. J. Plankton Res. 2: 335-353

Slawyk, G., Collos, Y., Minas, M., Grall, J.-R. (1978). On the relationship between carbon-to-nitrogen composition ratios of the particulate matter and growth rate of marine phytoplankton from the northwest African upwelling area. J. exp. mar. Biol. Ecol. 33: 119-131

Sokal, R. R., Rohlf, F. J. (1969). Biometry. W. H. Freeman, San Francisco

Taylor, C. D., Molongoski, J. J., Lohrenz, S. E. (1983). Instrumentation for the measurement of phytoplankton production. Limnol. Oceanogr. 28: 781-787

Tomas, C. R., Deason, E. E. (1981). The influence of grazing by two Acartia species on Olisthodiscus liteus Carter. P. S. Z. N. Mar. Ecol. 2: 215-223

Van Liere, L., Mur, L. R., Gibson, C. E., Herdman, M. (1979). Growth and physiology of Oscillatoria agardhii Gomont cultivated in continuous culture with a light-dark cycle. Arch. Mikrobiol. 123: 315-318

Verity, P. G., Stoecker, D. (1982). Effects of Olisthodiscus luteus on the growth and abundance of tintinnids. Mar. Biol. 72: 79-87

Zeitzschel, B. (1970). The quantity, composition, and distribution of suspended particulate matter in the Gulf of California. Mar. Biol. 7: 305-318 